\title{
AKTIVITAS ANTIOKSIDAN DAN ANTIHIPERKOLESTEROLEMIA IN VITRO DARI CAMPURAN EKSTRAK ANGKAK DAN BEKATUL
}

\author{
[In Vitro Antioxidant and Antihypercholesterolemia Activity of a Mixture \\ of Red Yeast Rice and Rice Bran Extracts]
}

\author{
Hasim $^{1) \star}$, Qomariah Hasanah"), Dimas Andrianto ${ }^{1)}$, dan Didah Nur Faridah ${ }^{2,3)}$ \\ 1) Departemen Biokimia, Fakultas Matematika dan IImu Pengetahuan Alam, Institut Pertanian Bogor, Bogor \\ 2) Departemen IImu dan Teknologi Pangan, Fakultas Teknologi Pertanian, Institut Pertanian Bogor, Bogor \\ ${ }^{3)}$ Southeast Asian Food and Agricultural Science and Technology (SEAFAST) Center, Institut Pertanian Bogor, Bogor
}

Diterima 18 September 2017 / Disetujui 24 September 2018

\begin{abstract}
Red yeast rice $(R Y R)$ and rice bran $(R B)$ have been reported to have many biological activities, such as anticancer, antioxidant, antidiab etes and antihypercholesterolemia. This research aimed to determine the best fraction of RYR extract as a HMG CoA reductase inhibitor and the best ratio of the mixture of $R Y R$ and $R B$ extract fraction as a HMG CoA reductase inhibitor and an antioxidant using in vitro assays. $R Y R$ and $R B$ were individually extracted using ethanol $95 \%$, followed by liquid-liquid fractionation using $n$ hexane, dichloromethane, etyhl acetate, and water. The RYR extract fraction with the best HMG CoA reductase inhibition was then mixed with $R B$ extract in various ratios for $H M G$ CoA reductase inhibition test and antioxidant activity by FRAP method, as well as analysis of total phenolics and flavonoids content. The results showed that the strongest inhibitory effect to the HMG CoA reductase was found in the water fraction of $R Y R$ extract (37.37\%). The mixture of $R Y R$ and $R B$ water extract fractions with a ratio of $R Y R: R B$ 1:3 had the strongest inhibition (51.85\%) as compared to other ratios, followed by a ratio of 2:2 (51.03\%) and 3:1 (42.36\%). The best antioxidant activity was found in the RYR:RB ratio of 1:3 (24.76 mg $T E / g)$. The highest total phenolic and flavonoid content was found in the $R Y R: R B$ ratio of 2:2 $(11.17 \mathrm{mg}$ $G A E / g)$ and the $R Y R: R B$ ratio of $3: 1(7.44 \mathrm{mg} Q E / g)$. Overall, the addition of $R B$ extract into the $R Y R$ extract was able to provide a significantly better HMG CoA reductase inhibitory effects and antioxidant activity than RYR extract alone.
\end{abstract}

Keywords: antihypercholesterolemia, antioxidant, HMG COA reductase, red yeast rice, rice bran

\section{ABSTRAK}

Angkak dan bekatul memiliki banyak manfaatbiologis, diantaranya sebagai antihiperkolesterolemia dan antioksidan. Penelitian ini bertujuan untuk menentukan fraksi terbaik dari eks trak angkak sebagai inhibitor HMG KoA reduktase serta menentukan rasio terbaik dari campuran fraksi eks trak angkak dan bekatul sebagai inhibitor HMG KoA reduktase dan antioksidan secara in vitro. Angkak dan bekatul diekstrak menggunakan etanol dilanjutkan dengan fraksinasi cair-cair menggunakan pelarut $n$-heksana, diklorometana, etil as etat, dan air. Fraksi ekstrak angkak dengan penghambatan HMG KoA reduktase terbaik kemudian dicampur dengan ekstrak bekatul pada berbagai rasio (angkak:bekatul) untuk pengujian penghambatan HMG KoA reduktase dan aktivitas antioksidan dengan metode FRAP sekaligus analisis kandungan total fenol dan flavonoid. Hasil pengujian menunjukkan bahwa efek penghambatan HMG KoA reduktase terkuat terdapat pada fraksi air eks trak angkak (37,37\%). Campuran fraksi air eks trak angkak dan bekatul menunjukkan bahwa rasio 1:3 memiliki penghambatan terkuat di antara rasio lainnya $(51,85 \%)$, berturut-turut diikuti oleh rasio $2: 2(51,03 \%)$ dan rasio $3: 1(42,36 \%)$. Aktivitas antioksidan paling baik yaitu pada rasio campuran $1: 3(24,76 \mathrm{mg}$ TE/g), total fenol tertinggi pada rasio campuran $2: 2(11,17 \mathrm{mg} \mathrm{GAE} / \mathrm{g})$ dan total flavonoid tertinggi pada rasio campuran 3:1 (7,44 mg QE/g). Secara keseluruhan, penambahan ekstrak bekatul ke dalam ekstrak angkak mampu memberikan efek penghambatan HMG KoA reduktase dan aktivitas antioksidan yang lebih baik secara signifikan daripada ekstrak angkak saja.

Kata kunci: angkak, antihiperkolesterolemia, antioksidan, bekatul, HMG KoA reduktase

${ }^{*}$ Penulis Korespondensi:

E-mail: hasim@apps.ipb.ac.id 


\section{PENDAHULUAN}

Hiperkolesterolemia adalah suatu gejala klinis yang ditandai dengan peningkatan kadar kolesterol total dan kolesterol low density lipoprotein (LDL) dalam darah. Hiperkolesterolemia menjadi salah satu faktor resiko terjadinya penyakit jantung koroner (PJK) (WHO, 2015). PJK diakibatkan oleh aterosklerosis, yaitu suatu kondisi dimana terjadi penimbunan plak kolesterol pada dinding dalam pembuluh darah yang berujung pada penyempitan atau penyumbatan pembuluh darah (Okwuosa et al., 2016). Penimbunan plak kolesterol dalam dinding pembuluh darah dapat terjadi ketika molekul LDL teroksidasi oleh radikal bebas (Maiolino et al., 2013).

Peningkatan deposit kolesterol dalam kondisi hiperkolesterolemia sendiri menyebabkan perubahan sifat fisik membran sel yang memicu kebocoran radikal bebas oksigen dari mitokondria. Radikal bebas oksigen ini mengakibatkan proses peroksidasi lemak di membran sel yang menghasilkan radikal peroksida dan radikal bebas lainnya (Singh et al., 2017). Oleh karena itu jika terjadi peningkatan radikal bebas dalam tubuh dibutuhkan antioksidan dalam jumlah yang lebih besar untuk menetralisir efek radikal bebas. Upaya meningkatkan status antioksidan dalam tubuh dapat dilakukan dengan mengonsumsi bahan pangan yang kaya akan antioksidan (Valko et al., 2007)

HMG KoA reduktase adalah enzim yang mengkatalis proses konversi HMG KoA menjadi asam mevalonat. Proses konversi tersebut merupakan tahapan vital dari biosintesis kolesterol di dalam tubuh. Penghambatan terhadap HMG KoA reduktase dilaporkan dapat menurunkan kadar kolesterol pada manusia dan hewan coba (Baskaran et al., 2015). Beberapa obat-obatan sintetis seperti mevionolin, simvastin dan pravastatin diketahui dapat menghambat reaksi pembentukan kolesterol (Pichandi et al., 2011). Namun obat-obatan sintetis ini memiliki efek samping seperti mual dan peningkatan tekanan darah. Oleh sebab itu perlu dicari bahan alami yang dapat dimanfaatkan sebagai pangan fungsional antihiperkolesterolemia.

Bahan alami yang memiliki potensi sebagai pangan fungsional antihiperkolesterolemia dan antioksidan salah satunya adalah angkak. Angkak merupakan hasil fermentasi beras menggunakan kapang Monascus purpureu yang dan mengandung pigmen rubropunktatin, monaskorubin dan ankaflavin yang berwarna merah (Kawuri, 2013). Angkak mengandung metabolit sekunder seperti lovastatin, isoflavon, sterol, asam lemak tidak jenuh dan vitamin B kompleks (Goufo et al., 2014). Dari beberapa studi in-vivo diketahui bahwa angkak mampu menurunkan kadar total serum kolesterol sebesar $19-44 \%$ pada manusia (Liu et al., 2006) dan 49,28\% pada tikus (Kasim et al., 2006), serta meningkatkan aktivitas glutation peroksidase (salah satu antioksidan intrasel) dan mengatasi stres oksidatif (Kasim et al., 2012), meningkatan trombosit jika dikombinasikan dengan daun jambu biji (Hasim et al., 2015)

Selain angkak, bahan alam yang dapat dimanfaatkan sebagai antihiperkolesterolemia dan antioksidan adalah bekatul. Bekatul adalah bahan alam yang melimpah hasil samping dari proses penggilingan padi. Bekatul mengandung serat, gamma orizanol, tokoferol, tokotrianol, polikosanol, dan asam lemak tidak jenuh. Senyawa bioaktif gammaorizanol pada bekatul mampu berperan sebagai agen antihiperkolesterolemia (Cicero dan Derosa, 2005). Tokoferol dari bekatul juga mampu berperan sebagai antioksidan (Chan et al., 2013; Arab et al., 2011). Penelitian yang dilakukan Hasanah et al. (2016) melaporkan bahwa fraksi air ekstrak etanol bekatul memiliki penghambatan terkuat sebesar 65,46\% terhadap HMG KoA reduktase dibandingkan dengan fraksi n-heksana $(50,42 \%)$, diklorometana $(59,50 \%)$ dan etil asetat $(55,50 \%)$.

Studi in vitro mengenai kemampuan penghambatan angkak terhadap HMG KoA reduktase belum pernah dilakukan. Disamping itu, sebagai produk yang berasal dari beras/padi, belum diketahui apakah kedua produk tersebut dapat bekerja secara sinergis atau antagonis sebagai agen antihiperkolesterolemia dan antioksidan. Tujuan dari penelitian ini adalah untuk menentukan fraksi terbaik dari ekstrak angkak sebagai inhibitor HMG KoA reduktase serta menentukan rasio fraksi ekstrak angkak dan fraksi ekstrak bekatul dalam campuran kedua ekstrak tersebut yang terbaik sebagai inhibitor HMG KoA reduktase dan antioksidan secara in vitro.

\section{BAHAN DAN METODE}

\section{Bahan}

Bahan-bahan utama yang digunakan dalam penelitian ini adalah angkak komersial (Pazola, Bogor, Indonesia) yang diperoleh dari apotik di Kota Bogor dan bekatul (beras pandan wangi, Bogor, Indonesia) yang diperoleh dari tempat penggilingan padi di daerah Situ Gede Bogor.

\section{Preparasi sampel dan ekstraksi angkak (Ismail et al., 2016)}

Angkak komersial dikeringkan dalam oven (Eyela NDO-700, Japan) selama 6 jam pada suhu $50^{\circ} \mathrm{C}$ kemudian dihaluskan dengan blender (Panasonic, Japan) dan diayak dengan saringan 40 mesh agar diperoleh keseragaman ukuran partikel sampel.

Ekstraksi secara maserasi diawali dengan cara memasukkan $1 \mathrm{~g}$ serbuk angkak ke dalam erlenmenyer $50 \mathrm{~mL}$ (Pyrex, Indonesia) kemudian ditambahkan pelarut etanol 95\% (PT. Dwi Prima Jaya, Indonesia) sebanyak $20 \mathrm{~mL}$. Larutan kemudian di- 
aduk menggunakan shaker (Zhengji HY-4A, China) selama 2 jam pada kecepatan 130 rpm. Larutan ekstrak kemudian disaring menggunakan kertas saring, sedangkan residunya diekstraksi kembali sebanyak 2 kali. Ekstrak yang diperoleh dikeringkan dengan rotary evaporator (Ogawa, Japan) pada suhu $45^{\circ} \mathrm{C}$ dan selanjutnya ditimbang.

Ekstrak etanol angkak selanjutnya difraksinasi menggunakan n-heksan, diklorometan, etil asetat dan air. Semua hasil fraksinansi dan ekstrak kasar etanol angkak diuji penghambatannya terhadap HMG-KoA reduktase. Fraksi terbaik angkak dipilih dan dikombinasikan dengan fraksi air ekstrak etanol bekatul (Hasanah et al., 2016).

\section{Preparasi sampel dan ekstraksi bekatul (Hasanah et al., 2016)}

Bekatul segar diayak terlebih dahulu dengan saringan 40 mesh. Bekatul selanjutnya dipanaskan dengan oven pada suhu $150^{\circ} \mathrm{C}$ selama 10 menit lalu didinginkan pada suhu kamar selama 30 menit. Pemanasan tersebut bertujuan untuk menghindarkan bekatul dari ketengikan yang timbul akibat degradasi komponen lemak bekatul selama masa penyimpanan. Suhu tinggi di atas $120^{\circ} \mathrm{C}$ akan menyebabkan denaturasi enzim-enzim yang memicu degradasi komponen lemak tanpa merusak nilai gizi dari bekatul tersebut. Selanjutnya sampel bekatul disimpan dalam pendingin pada suhu $4^{\circ} \mathrm{C}$ selama satu minggu sebelum dianalisis.

Ekstraksi secara maserasi diawali dengan cara melarutkan $5 \mathrm{~g}$ bekatul dengan $20 \mathrm{~mL}$ etanol 95\%. Larutan kemudian diaduk menggunakan shaker selama 3 jam pada kecepatan 130 rpm. Larutan ekstrak kemudian disaring menggunakan kertas saring, sedangkan residunya diekstraksi kembali sebanyak 2 kali. Ekstrak yang diperoleh dikeringkan dengan rotary evaporator pada suhu $50^{\circ} \mathrm{C}$ dan selanjutnya ditimbang.

\section{Fraksinasi ekstrak angkak dan bekatul (Andrianto et al., 2015)}

Ekstrak etanol angkak dan bekatul selanjutnya difraksinasi secara ekstraksi cair-cair menggunakan pelarut dengan kepolaran yang semakin meningkat yaitu pelarut $n$-heksana ( $T$ \& T chemical, Indonesia), diklorometana (Jinan Shijitongda Chemical Co, Ltd, China), etil asetat (PT. Dwi Prima Jaya, Indonesia) dan air. Lapisan yang terbentuk dari hasil fraksinasi dipekatkan dengan rotary evaporator.

\section{Uji penghambatan HMG-KoA reduktase \\ (Andrianto et al., 2015)}

Aktivitas antihiperkolesterolemia dari masingmasing sampel ditentukan dari aktivitas penghambatannya terhadap HMG KoA reduktase. Setiap sampel disiapkan dengan konsentrasi $10 \mathrm{mg} / \mathrm{mL}$ dalam 5\% larutan DMSO (Merck, Germany). Pravasta- tin (Sigma-Aldrich, St.Lous, MO, USA) sebagai kontrol positif disiapkan dalam larutan $50 \mu \mathrm{g} / \mathrm{mL}$. $3 \mu \mathrm{L}$ sampel ditambahkan ke campuran reaksi termasuk $100 \mathrm{mM}$ bufer kalium fosfat (Sigma-Aldrich, St.Lous, $\mathrm{MO}$, USA) (400 mM KCl, $100 \mu \mathrm{g} / \mathrm{mL}$ serum albumin bovine dan 3,5 mM EDTA), NADPH (Sigma-Aldrich, St.Lous, MO, USA) (250 $\mu \mathrm{M})$ dan HMG KoA (Sigma -Aldrich, St.Lous, MO, USA) $(250 \mu \mathrm{M})$ (volume akhir $557 \mu \mathrm{L})$. Reaksi dimulai dengan penambahan $3 \mu \mathrm{L}$ HMG KoA reduktase (Sigma-Aldrich, St.Lous, MO, USA) $(50 \mu \mathrm{g} / \mathrm{L})$. Campuran reaksi di kocok selama 10 detik dan absorbansi diukur pada panjang gelombang $340 \mathrm{~nm}$ setiap 15 detik sampai 6 menit. Aktivtas enzim dinyatakan dalam unit/mg protein dan dihitung dengan persamaan:

$$
\frac{\left(\Delta \mathrm{A}_{340} / \mathrm{min}_{\text {sampel }}-\Delta \mathrm{A}_{340} / \mathrm{min}_{\text {blanko }}\right)}{12,44 \times \mathrm{V} \times 0,6 \times \mathrm{LP}}
$$

dimana, $A_{340}$ adalah absorbansi, $V$ adalah volume enzim yang digunakan dan LP adalah lebar larutan yang dilewati sinar, 0.6 adalah konsentrasi enzim dalam mg protein/ $\mathrm{mL}$ dan 12,44 adalah kebutuhan NADPH selama reaksi (koefisien untuk NADPH pada $340 \mathrm{~nm}$ adalah 6,22/mM.cm). Untuk persentase inhibisi dihitung menggunakan persamaan:

$$
\text { Penghambatan (\%) }=\frac{\left(\text { aktivitas }_{\text {enzim }} \text {-aktivitas }_{\text {sampel }}\right)}{\text { aktivitas }_{\text {enzim }}} \times 100 \%
$$

\section{Campuran fraksi ekstrak angkak dan fraksi air ekstrak bekatul}

Pencampuran dengan beberapa rasio dilakukan antara fraksi ekstrak etanol angkak yang memiliki penghambatan terbaik terhadap HMG KoA reduktase dengan fraksi air ekstrak bekatul. Dari ekstrak bekatul dipilih fraksi air karena fraksi tersebut memiliki inhibisi HMG KoA reduktase terbaik berdasarkan penelitian Hasanah et al. (2016). Rasio fraksi air ekstrak angkak terhadap bekatul yang digunakan adalah $3: 1,2: 2$ dan $1: 3$. Pada setiap campuran dengan rasio ekstrak tersebut dilakukan uji penghambatan HMG KoA reduktase, aktivitas antioksidan, total fenol serta total flavonoid.

\section{Uji aktivitas antioksidan dengan analisis reduksi Fe (Benzie dan Strain, 1996; Tananuwong dan Tewaruth, 2010)}

Analisis aktivitas antioksidan menggunakan reagen ferric reducing antioxidant power (FRAP) yang terdiri atas larutan bufer asetat $300 \mathrm{mM}(\mathrm{pH}$ 3.6), larutan 2,4,6-tripydyl-s-triazine (TPTZ) (SigmaAldrich, St.Lous, MO, USA) $10 \mathrm{mM}$ dalam $\mathrm{HCl} 40$ (Merck, Germany) $\mathrm{mM}$ dan larutan $\mathrm{FeCl}_{3} .6 \mathrm{H}_{2} \mathrm{O}$ (Sigma-Aldrich, St.Lous, MO, USA) 20 mM. Reagent FRAP disiapkan dengan cara mencampurkan $25 \mathrm{~mL}$ buffer asetat, 2,5 mL larutan TPTZ dan 2,5 mL larutan $\mathrm{FeCl}_{3} \cdot 6 \mathrm{H}_{2} \mathrm{O}$. Pencampuran dilakukan sesaat se- 
belum analisis, reagen FRAP diinkubasi terlebih dahulu pada suhu $37^{\circ} \mathrm{C}$ selama 30 menit kemudian siap untuk digunakan. Reagen FRAP tersebut juga digunakan sebagai blanko. Larutan standar yang digunakan adalah trolox dengan rentang konsentrasi 50-500 ppm.

Analisis dilakukan dengan cara mencampurkan $10 \mu \mathrm{L}$ sampel dengan $990 \mu \mathrm{L}$ reagen FRAP. Setelah itu campuran tersebut dihomogenkan dan diinkubasi selama 4 menit pada suhu ruang kemudian absorbansinya diukur pada panjang gelombang $593 \mathrm{~nm}$ menggunakan spektrofotometer UV-Vis (Genesys 10UV, Thermo scientific-USA). Hasil absorbansi sampel yang diperoleh dapat dihitung dalam trolox ekuivalen (trolox equivalent/TE) menggunakan kurva standar.

\section{Penentuan kandungan total fenol (Vongsak et al., 2012)}

Total senyawa fenolik ditentukan dengan menggunakan prosedur Folin-Ciocalteu (Merck, Germany). Setiap sampel $(1000 \mu \mathrm{g} / \mathrm{mL})$ sebanyak $200 \mu \mathrm{L}$ dicampur dengan $500 \mu \mathrm{L}$ reagen Folin-Ciocalteu (diencerkan 1:10 dengan akuades) dan $800 \mu \mathrm{L}$ larutan natrium bikarbonat (Merck, Germany) (7,5\%, w/v). Campuran diinkubasi pada suhu kamar selama 30 menit kemudian absorbansi diukur pada panjang gelombang $765 \mathrm{~nm}$ menggunakan spektrofotometer UV-Vis (Genesys 10UV, Thermo scientific-USA). Kandungan total senyawa fenol dihitung sebagai rata-rata $\pm S D(n=3)$ dan dinyatakan sebagai $\mathrm{mg}$ ekivalen asam galat (GAE) per g ekstrak.

\section{Penentuan kandungan total flavonoid (Vongsak et al., 2012) \\ Total flavonoid dianalisis dengan menggunakan aluminium klorida (Merck, Germany) kolorimetri. Sampel $(1000 \mu \mathrm{g} / \mathrm{mL})$ sebanyak $0,5 \mathrm{~mL}$ dicampur dengan $0,5 \mathrm{~mL}$ larutan aluminium klorida $2 \%$. Cam- puran dibiarkan pada suhu kamar selama 10 menit dan absorbansi campuran diukur pada panjang ge- lombang $415 \mathrm{~nm}$ menggunakan spektrofotometer UV-Vis.Total flavonoid dihitung sebagai rata-rata \pm SD $(n=3)$ dan dinyatakan sebagai mg ekivalen kuer- setin (QE) per g ekstrak.}

\section{Analisis statistik}

Analisis statistik dikerjakan dengan bantuan program SPSS versi 21. Semua pengukuran dilakukan sebanyak tiga kali. Data disajikan sebagai nilai rata-rata dengan standar deviasi (SD). Data Dianalisis melalui perbandingan nilai rata-rata yang dilakukan menggunakan ANOVA, dilanjutkan dengan uji Duncan $(P<0,05)$.

\section{HASIL DAN PEMBAHASAN}

\section{Hasil ekstraksi dan fraksinasi}

Rendemen ekstrak etanol 95\% angkak yang diperoleh adalah 10,13 $\pm 0,07 \%$ (w/w). Penggunaan beberapa pelarut yang berbeda tingkat kepolarannya dalam fraksinasi bertujuan agar komponen aktif dapat terekstrak berdasarkan polaritasnya. Rendemen hasil fraksinasi ekstrak etanol angkak adalah

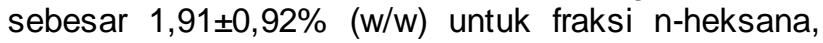

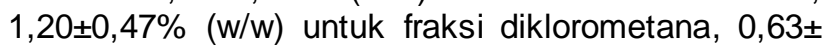
$0,20 \%(w / w)$ untuk fraksi etil asetat dan 1,45 $\pm 1,07 \%$ (w/w) untuk fraksi air.

Hasil ANOVA menunjukkan bahwa penggunaan jenis pelarut yang berbeda tidak menghasilkan jumlah rendemen yang berbeda signifikan $(P>0,05)$. Hal tersebut mengindikasikan bahwa ekstrak etanol angkak mengandung berbagai senyawa dengan polaritas yang beragam dalam jumlah yang relatif seimbang satu sama lain.

\section{Penghambatan enzim HMG KoA reduktase ekstrak dan fraksi angkak}

Hasil penelitian menunjukkan bahwa penghambatan terhadap HMG KoA reduktase dari fraksi air $(37,37 \%)$, fraksi etil asetat $(35,61 \%)$, fraksi diklorometana $(32,14 \%)$ dan ekstrak etanol $(33,35 \%)$ tidak berbeda signifikan (Gambar 1) Untuk penelitian pada tahap selanjutnya yaitu campuran angkak dan bekatul, fraksi air angkak yang terpilih karena nilai rata-rata penghambatannya lebih besar dibandingkan dengan ekstrak etanol dan fraksi lainnya.

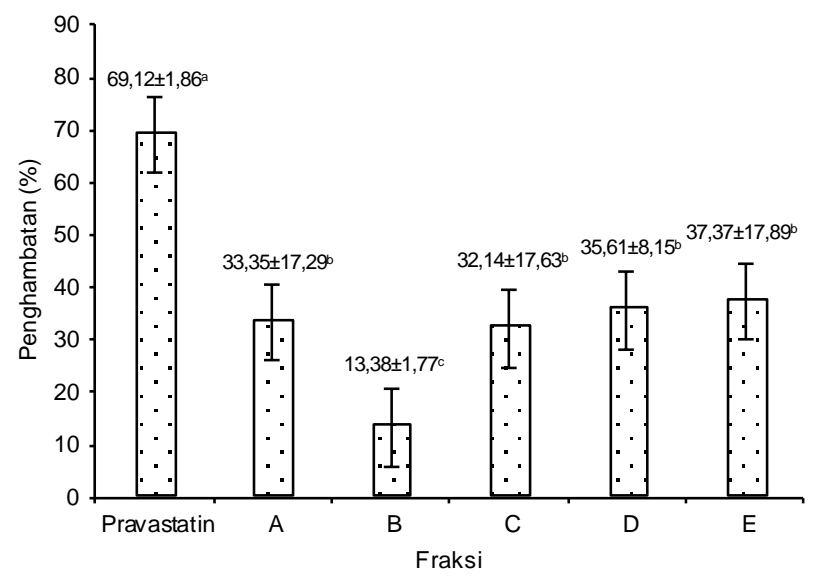

Gambar 1. Penghambatan ekstrak dan fraksi ekstrak angkak terhadap $\mathrm{HMG}$ KoA reduktase. $A=$ ekstrak etanol; $B=$ fraksi $n$ heksana; $C$ = fraksi diklorometana; $D=$ fraksi etil asetat; $E=$ fraksi air. Nilai dinyatakan dalam rata-rata $\pm S D$ dari tiga kali ulangan untuk setiap fraksi dengan konsentrasi $50 \mu \mathrm{g} / \mathrm{L}$. Nilai yang diikuti oleh huruf kecil yang berbeda menunjukkan perbedaan nyata $(P<0,05)$ 
Hal tersebut menandakan bahwa senyawa yang memiliki kemampuan menghambat HMG KoA reduktase lebih banyak berkumpul pada fraksi semi polar hingga polar yakni fraksi diklorometana, etil asetat dan air. Oleh sebab itu, n-heksana yang merupakan pelarut non polar menghasilkan fraksi ekstrak dengan penghambatan terlemah (13,38\%). Uji fitokimia yang dilakukan oleh Ismail et al. (2016) juga memperlihatkan bahwa komponen bioaktif yang terdapat dalam fraksi air ekstrak etanol angkak lebih dominan bersifat polar seperti flavonoid (golongan glikosida) dan alkaloid. Perbedaan penghambatan disebabkan oleh perbedaan kandungan metabolit sekunder yang diperoleh dari ekstraksi dan fraksinasi dengan pelarut yang berbeda. Perbedaan penghambatan ini juga ditunjukkan dalam penelitian yang dilakukan oleh Andrianto et al. (2015) dengan menggunakan sampel phyllanthus acidus dimana fraksi etil asetat memiliki penghambatan paling kuat terhadap HMG KoA reduktase $(87,30 \%)$ sedangkan yang paling rendah adalah fraksi diklorometana (53,98\%).

Monakolin $\mathrm{K}$ merupakan senyawa yang terbentuk oleh Monascus selama proses fermentasi dan terbukti memberikan efek bagi penderita gangguan kardiovaskular dengan menghambat reaksi kritis dalam jalur sintesis kolesterol dalam pembentukan asam mevalonat dari 3-hidroksi-3 methylglutaryl CoA (HMG-KoA) oleh HMG-KoA reduktase (Mei et al., 2011). Monakolin $\mathrm{K}$ secara struktural mirip dengan lovastatin, obat statin yang pertama diperjualbelikan, memainkan peran sebagai inhibitor kompetitif yang bersaing dengan HMG-KoA dalam mengurangi sintesis kolesterol (Lachenmeier et al., 2012).

Penghambatan ekstrak angkak hasil dari penelitian ini lebih kecil bila dibandingkan dengan penghambatan bekatul pada penelitian Hasanah et al. (2016) dan beberapa penelitian lain. Pada Tabel 1 dapat dilihat efek penghambatan HMG-KoA reduktase dari berbagai bahan alami dengan nilai penghambatan sekitar $20-84 \%$.

\section{Campuran ekstrak angkak dan bekatul}

Hasil penelitian menunjukkan bahwa penambahan fraksi air ekstrak bekatul pada fraksi air ekstrak angkak akan meningkatkan penghambatan terhadap HMG KoA reduktase (Gambar 2). Penghambatan terkuat terdapat pada campuran ekstrak dengan rasio angkak terhadap bekatul 1:3 sebesar $51,85 \%$ (Gambar 2).

Dari hasil tersebut menunjukkan bahwa antara senyawa metabolit sekunder dan bioaktif yang berasal dari angkak dan bekatul memberikan hasil yang tidak sinergis tetapi hanya bersifat aditif, sehingga campuran angkak dan bekatul dapat direkomendasikan sebagai pangan fungsional penurun kolesterol, walaupun efek penurun kolesterol yang dihasilkan bekatul murni masih lebih baik. Fraksi air ekstrak bekatul mempunyai penghambatan terhadap HMG
KoA reduktase yang paling kuat $(65,46 \%)$ dibandingkan dengan fraksi air ekstrak angkak dan campuran keduanya pada beberapa rasio. Belum ada penelitian lainnya mengenai penghambatan HMG KoA reduktase oleh kombinasi angkak dan bekatul. Akan tetapi pada penelitian yang telah dilakukan oleh Wahyuningrum dan Zubaidah (2016) mengenai pengaruh pemberian angkak dengan penambahan bekatul pada tikus hiperkolesterolemia menunjukkan adanya aktivitas penurun kolesterol total sebesar $80,50 \mathrm{mg} / \mathrm{dl}$ dan trigliserida $46,00 \mathrm{mg} / \mathrm{dl}$ bila dibandingkan dengan pemberian angkak saja dimana kolesterol total menurun sebesar $94,00 \mathrm{mg} / \mathrm{dl}$ dan trigliserida sebesar $63,75 \mathrm{mg} / \mathrm{dl}$. Bekatul mengandung komponen bioaktif berupa gamma orizanol, tokoferol, dan tokotrienol yang berperan sebagai agen antioksidan dan antikolesterol (Moongngarm et al., 2012) yang juga dapat menghambat HMG KoA reduktase.

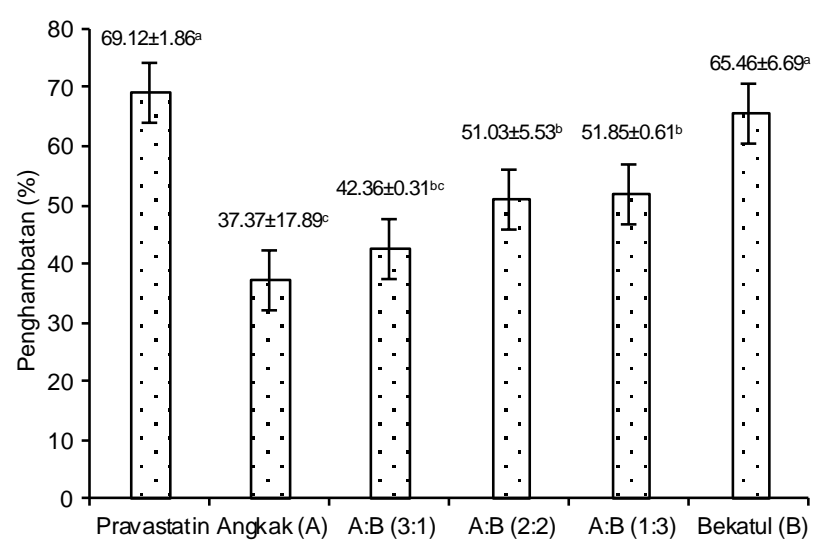

Gambar 2. Perbandingan efek penghambatan fraksi air ekstrak angkak dan bekatul serta campuran keduanya pada beberapa rasio terhadap $\mathrm{HMG}$ KoA reduktase. $A=$ fraksi air ekstrak etanol angkak, $B=$ fraksi air ekstrak etanol bekatul. Nilai dinyatakan dalam rata-rata $\pm S D$ dari tiga kali ulangan untuk setiap formula. Nilai yang diikuti oleh huruf kecil yang berbeda menunjukkan perbedaan nyata $(P<0,05)$. Nilai penghambatan fraksi air ekstrak etanol bekatul diambil dari Hasanah et al. (2016)

\section{Aktivitas antioksidan}

Analisis antioksidan dengan menggunakan metode FRAP bertujuan untuk mengukur kemampuan sampel dalam mereduksi $\mathrm{Fe}^{3+}$ menjadi $\mathrm{Fe}^{2+}$ sehingga membentuk komplek $\mathrm{Fe}^{3+} \mathrm{TPTZ}$ dengan cara mendonorkan elektron yang dihasilkan dari senyawa antioksidan. Nilai FRAP tergantung pada banyaknya reduksi ferritripyridyl triazine (Fe(III)-TPTZ) menjadi ferro-tripyridyltriazine (Fe(II)-TPTZ) oleh sampel pada kondisi $\mathrm{pH}$ rendah. Kompleks tersebut akan menghasilkan warna biru. 
Tabel 1. Penghambatan HMG KoA reduktase dari angkak, bekatul dan beberapa bahan alami lainnya

\begin{tabular}{|c|c|c|c|}
\hline Sampel & Pelarut & Penghambatan (\%) & Sumber \\
\hline \multirow{5}{*}{ Angkak (Red yeast rice) } & Etanol & 33,35 & \multirow[t]{5}{*}{ Hasil penelitian ini } \\
\hline & Fraksin-heksana & 13,38 & \\
\hline & $\begin{array}{l}\text { Fraksi } \\
\text { diklorometana }\end{array}$ & 32,14 & \\
\hline & Fraksi etil asetat & 35,61 & \\
\hline & Fraksi air & 37,37 & \\
\hline \multirow[t]{5}{*}{ Bekatul (Rice bran) } & Etanol & 51,44 & \multirow{5}{*}{$\begin{array}{l}\text { Hasanah etal., } \\
2016\end{array}$} \\
\hline & Fraksin-heksana & 50,42 & \\
\hline & $\begin{array}{l}\text { Fraksi } \\
\text { diklorometana }\end{array}$ & 59,50 & \\
\hline & Fraksi etil asetat & 55,50 & \\
\hline & Fraksi air & 65,46 & \\
\hline Kulit buah matang jamblang (Syzigium cumini) & Aseton & 45,96 & \multirow{9}{*}{$\begin{array}{l}\text { Andrianto et al., } \\
2015\end{array}$} \\
\hline Biji muda binjai (Mangifera caesia Jack) & Metanol & 46,45 & \\
\hline Biji matang binjai (Mangifera caesia Jack) & Metanol & 47,63 & \\
\hline Biji matang jamblang (Syzigium cumini) & Aseton & 49,27 & \\
\hline Biji muda jamblang (Syzigium cumini) & Aseton & 50,39 & \\
\hline Kulit buah matang menteng (Baccaurea racemosa) & Metanol & 59,84 & \\
\hline Kulit buah muda menteng (Baccaurea racemosa) & Aseton & 70,37 & \\
\hline Kulit buah matang menteng (Baccaurea racemosa) & Aseton & 71,65 & \\
\hline Buah matang cermai (Phylanthus acidus (L)) & Aseton & 80,00 & \\
\hline Daun (Verbascum songaricum) & Metanol & 36,80 & \multirow{18}{*}{$\begin{array}{l}\text { Gholamhoseinian } \\
\text { et al., } 2010\end{array}$} \\
\hline Bibit flax (Linum usitatissimum) & Metanol & 37,00 & \\
\hline Akar (Peucadanum aucheri) & Metanol & 37,00 & \\
\hline Daun zaitun (Olea europaea) & Metanol & 37,00 & \\
\hline Daun mint (Mentha piperita) & Metanol & 37,30 & \\
\hline Batang (Gundelia tournefortii) & Metanol & 40,00 & \\
\hline Buah merica hitam (Piperningrum) & Metanol & 40,00 & \\
\hline Batang (Urtica ureus) & Metanol & 40,00 & \\
\hline Daun pacar kuku (Lawsonia inermis) & Metanol & 40,10 & \\
\hline Batang (Stachys lavaudulifolia) & Metanol & 42,00 & \\
\hline Rhizoma (Rheum ribes) & Metanol & 43,00 & \\
\hline Batang (Thymus serpyllum) & Metanol & 43,60 & \\
\hline Batang selasih (Metha longifolia) & Metanol & 44,00 & \\
\hline Daun dafnah (Lourus nobilis) & Metanol & 44,40 & \\
\hline Akar lovage (Levisticum officinale) & Metanol & 48,00 & \\
\hline Daun murad (Myrtus communis) & Metanol & 62,00 & \\
\hline Bagian bunga mawar (Rosa damascene) & Metanol & 70,00 & \\
\hline Getah manjakani (Quercus infectoria) & Metanol & 84,00 & \\
\hline Pepaya (Carica papaya) & Metanol & 37,30 & \multirow{4}{*}{$\begin{array}{l}\text { Baskaran etal., } \\
2015\end{array}$} \\
\hline Daun sirih (Piper sarmentosum) & Metanol & 55,10 & \\
\hline Bayam (Amaranthus viridis) & Metanol & 69,60 & \\
\hline Berri hitam (Basella alba) & Metanol & 74,10 & \\
\hline Ficus palmatforsk & Metanol & 65,00 & \multirow{5}{*}{$\begin{array}{l}\text { lqbal et al., } 2014 \\
\text { Koo et al., } 2008 \\
\text { Salvamani et al., } \\
2016\end{array}$} \\
\hline Anggur (Vitis vinifera bark) & Metanol & 77,00 & \\
\hline Daun bayam hijau (Amaranthus viridis) & Metanol & 72,00 & \\
\hline Biji bayam hijau (Amaranthus viridis) & Metanol & 35,00 & \\
\hline Batang bayam hijau (Amaranthus viridis) & Metanol & 22,00 & \\
\hline
\end{tabular}

Fraksi air ekstrak bekatul memiliki aktivitas antioksidan paling besar bila dibandingkan dengan fraksi air ekstrak angkak maupun campuran keduanya yaitu sebesar 31,90 (mg TE/g) (Gambar 3). Campuran keduanya yang memiliki aktivitas antioksidan terbesar adalah campuran dengan rasio angkak terhadap bekatul 1:3 (24,76 mg TE/g). Aktivitas antioksidan yang dihasilkan oleh campuran dengan rasio tersebut berbeda signifikan dengan yang dihasilkan oleh fraksi air ekstrak angkak (18,73 mg TE/g). Hal ini menunjukkan bahwa bekatul memiliki komponen bioaktif lebih baik daripada angkak dalam mereduksi senyawa Fe. Kim dan Lim (2016) melaporkan ekstrak etanol $50 \%$ bekatul memiliki aktivitas antioksidan dengan metode FRAP sebesar 20-21 ( $\mu \mathrm{M}$ $\mathrm{FeSO}_{4} / \mathrm{g}$ ), lebih rendah bila dibandingkan dengan penelitian ini.

Yeap et al. (2014) melaporkan ekstrak air angkak mempunyai aktivitas antioksidan dengan metode ferric reducing antioxidan power (FRAP) sebesar 
74,04 (mg asam askorbat/g) sedangkan dalam penelitian ini fraksi air angkak memiliki kemampuan antioksidan sebesar 18,73 (mg TE/g). Ekstrak air angkak yang dianalisis dengan HPLC terbukti mengandung senyawa gamma-aminobutyric acid (GABA) dan asam lemak bebas yang terbukti berperan membantu proses antioksidan (Yeap et al., 2014). Antioksidan memiliki peran penting dalam mengurangi lesi ateroskelosis. Antioksidan akan menangkap radikal bebas yang dapat menyerang LDL menjadi LDL teroksidasi yang merupakan penyebab terjadinya aterosklerosis didalam sel endotelium (Maiolino et al., 2013).

\section{Total fenol dan total flavonoid}

Total fenol sampel diketahui berdasarkan kemampuan senyawa fenolik dalam mereduksi asam fosfomolibdat-fosfotungstat dalam pereaksi FolinCiocalteu yang dapat menghasilkan senyawa kompleks molibdenum-tungsten berwarna biru. Asam galat digunakan sebagai standar dalam penentuan total fenol disebabkan oleh adanya gugus hidroksi dan ikatan rangkap terkonjungasi pada cincin benzena sehingga sangat efektif membentuk kompleks dengan pereaksi Folin-Ciocalteu. Selain itu asam galat merupakan golongan fenol sederhana dengan ketersediaan substansi yang stabil dan murni.

Analisis kandungan total fenol menunjukkan bahwa campuran fraksi air ekstrak angkak dan fraksi air ekstrak bekatul juga memberikan hasil yang tidak sinergis tetapi hanya bersifat aditif. Total fenol terus meningkat dengan adanya penambahan konsentrasi bekatul. Campuran keduanya yang memiliki total fenol tertinggi adalah campuran dengan rasio angkak terhadap bekatul 2:2 (11,17 mg GAE/g). Fraksi air ekstrak bekatul memiliki total fenol paling tinggi yaitu sebesar 14,54 (mg GAE/g) (Gambar 3). Pada penelitian Chan et al. (2013) ekstrak air bekatul memiliki total fenol sebesar 19,04 (mg GAE/g), lebih tinggi dari pada penelitian ini. Total fenol tergantung pada sampel bekatul yang digunakan. Total fenol pada campuran dengan rasio angkak terhadap bekatul 3:1 serta fraksi air ekstrak angkak memiliki total fenol yang sama yaitu sebesar 9,59 (mg GAE/g) (Gambar 3). Ekstrak air angkak memiliki total fenol sebesar 1,73 (mg GAE/g) (Razak et al., 2014) yang lebih rendah daripada penelitian ini.

Analisis total flavonoid juga menunjukkan bahwa campuran fraksi air ekstrak angkak dan fraksi air ekstrak bekatul tidak saling bersinergis dimana total flavonoid meningkat dengan adanya penambahan konsentrasi ekstrak angkak, berkebalikan dari aktivtas antioksidan dan total fenol. Campuran keduanya yang memiliki total flavonoid tertinggi adalah campuran dengan rasio angkak terhadap bekatul 3:1 (7,44 mg QE/g). Fraksi air ekstrak angkak memiliki total flavonoid paling tinggi yaitu sebesar 7,60 (mg $\mathrm{QE} / \mathrm{g}$ ) dan fraksi air ekstrak bekatul memiliki total flavonoid terendah yaitu 4,26 (mg QE/g) (Gambar 3). Menurut penelitian yang dilakukan oleh Ghasemzadeh et al. (2015) total flavonoid yang terdapat pada ekstrak etanol $50 \%$ bekatul sebesar 1,37 (mg QE/g). Untuk total flavonoid yang terdapat pada ekstrak etanol angkak 5,07 (mg QE/g) (Park dan Kim, 2011).

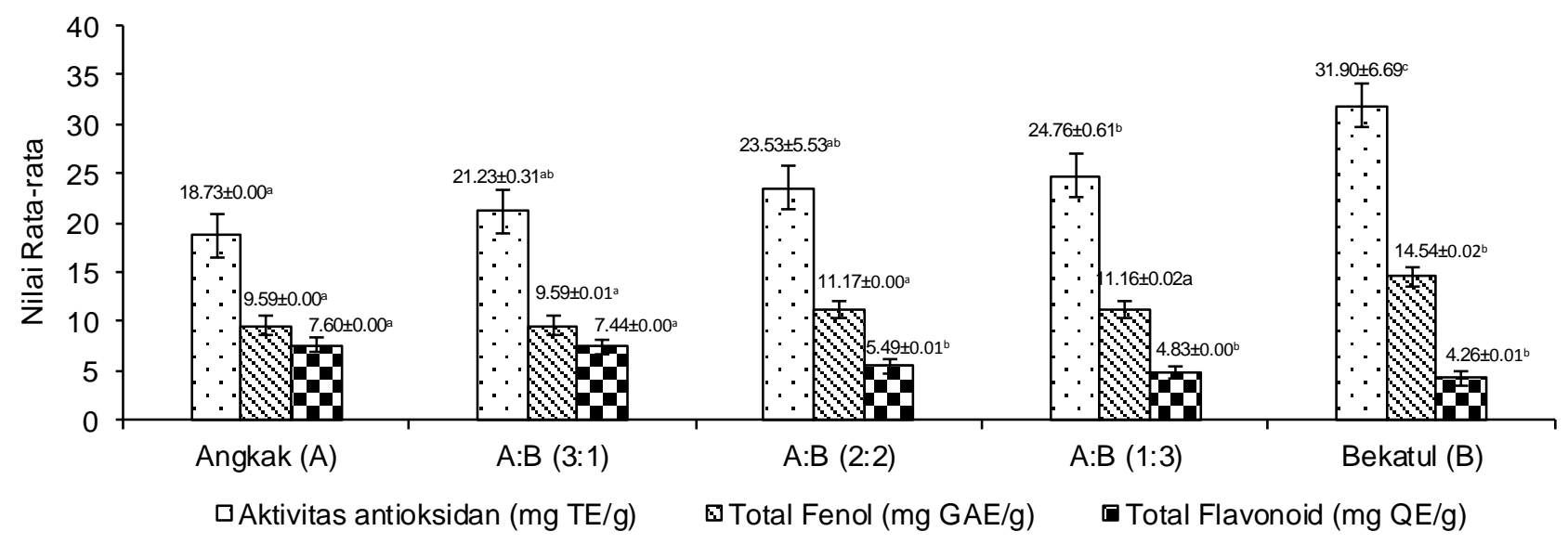

Gambar 3. Aktivitas antioksidan, total fenol dan total flavonoid dari kombinasi angkak dan bekatul. $\mathrm{A}=$ fraksi air ekstrak etanol angkak, B = fraksi air ekstrak etanol bekatul, TE = trolox equivalen, $\mathrm{GAE}=$ gallic acid equivalen, $\mathrm{QE}=$ quercetin equivalen. Nilai dinyatakan dalam rata-rata $\pm \mathrm{SD}$ dari tiga kali ulangan untuk setiap formula. Nilai yang diikuti oleh huruf kecil yang berbeda menunjukkan perbedaan nyata $(P<0,05)$. Nilai aktivitas antioksidan, total fenol dan total flavonoid fraksi air ekstrak etanol bekatul diambil dari Hasanah et al. (2016) 
Dari hasil analisis total fenol dan total flavonoid memperlihatkan bahwa keberadaan senyawa fenolik ternyata lebih mendominasi daripada flavonoid berkaitan dengan nilai aktivitas antioksidan. Tingginya aktivitas antioksidan sampel dapat dipengaruhi oleh kandungan senyawa turunan fenol yang memiliki gugus $-\mathrm{OH}$ yang tersubstitusi pada cincin benzena dengan posisi orto dan para terhadap gugus $-\mathrm{OH}$ dan -OR (Tursiman dan Nofiani, 2012).

Golongan flavonoid yang memiliki aktivitas antioksidan antara lain rutin dan kuersetin (Peng et al., 2015), katekin, eriodiktiol, dan taxifolin (Chobot et al., 2016). Flavonoid golongan glikosida yang larut dalam pelarut polar (fraksi air) diduga memiliki kemampuan sebagai antioksidan dalam penelitian ini. Menurut Badgujar et al. (2014) keberadaan senyawa flavonoid juga memiliki kontribusi sebagai senyawa antioksidan.

\section{KESIMPULAN}

Ekstrak etanol angkak, fraksi air, fraksi etil asetat, dan fraksi diklorometana memiliki efek penghambatan terhadap HMG KoA reduktase yang tidak berbeda nyata secara statistik, sedangkan efek penghambatan yang paling rendah adalah fraksi $n$ heksan. Campuran fraksi air ekstrak angkak dan fraksi air ekstrak bekatul pada berbagai rasio, memberikan hasil yang tidak sinergis tetapi hanya bersifat adiktif dalam menghambat HMG KoA reduktase dimana efek penghambatannya terus meningkat dengan penambahan bekatul. Oleh karena itu, campuran dengan rasio angkak terhadap bekatul 1:3 memiliki potensi paling tinggi diantara rasio lainnya sebagai pangan fungsional antihiperkolesterolemia dengan mekanisme penghambatan HMG KoA reduktase $(51,85 \%)$.

Campuran fraksi air ekstrak angkak dan fraksi air ekstrak bekatul juga meningkatkan aktivitas antioksidan. Aktivitas antioksidan yang paling baik dihasilkan oleh campuran dengan rasio angkak terhadap bekatul 1:3 yaitu sebesar $24,76 \mathrm{mg} \mathrm{TE} / \mathrm{g}$. Aktivitas antioksidan semakin tinggi dengan semakin banyaknya fraksi air bekatul yang ditambahkan

\section{UCAPAN TERIMAKASIH}

Terima kasih kepada Kemristek-Dikti yang sudah membiayai penelitian ini melalui Progam Penelitian Strategis Aplikatif pada tahun 2016.

\section{DAFTAR PUSTAKA}

Andrianto D, Katayama T, Suzuki T. 2015. Screening of antioxidant and antihyperlipidemic poten- cies of Indonesian underutilized fruits. J Forest Biomass Utilization Soc 1: 19-25.

Arab F, Alemzadeh I, Maghsoudi V. 2011. Determination of antioxidant component and activity of rice bran extract. Sci Iran 18: 1402-1406. DOI: 10.1016/j.scient.2011.09.014.

Badgujar SB, Patel VV, Bandivdekar AH. 2014. Foeniculum vulgare mill: $\mathrm{A}$ review of its botany phytochemistry, pharmacology, cotemporary application and toxicology. Biomed Res Int 2014: 132. DOI: 10.1155/2014/842674.

Baskaran G, Salvamani S, Ahmad SA, Shaharudin NA, Pattiram PD, Shukor MY. 2015. HMG-CoA reductase inhibitory activity and phythochomponent investigation of basella alba leaf extract as a treatment for hypercholesterolemia. Drug Des Devel Ther 9: 509-517. DOI: 10.2147/DDDT.S7 5056.

Benzie IFF, Strain JJ. 1996. The ferric reducing ability of plasma as a measure of "antioxidant power" the FRAP assay. Anal Biochem 239: 7076. DOI: $10.1006 /$ abio. 1996.0292 .

Chan KW, Khong NMH, lqbal S, Ismail M. 2013. Isolation and antioxidative properties of phenolicssaponins rich fraction from defatted rice bran. $J$ Cereal Sci 57: 480-485. DOI: 10.1016/j.jcs.20 13.02.002.

Chobot V, Hadacek F, Bachmann G, Weckwerth W, Kubicova L. 2016. Pro and antioxidant activity of three selected flavan type flavonoids: cathecin, eriodictyol, and taxifolin. Int J Mol Sci 17: 19. DOI: $10.3390 / \mathrm{ijms} 17121986$.

Cicero AFG, Derosa G. 2005. Rice bran and its mian component: Potential role in the management of coronary risk factors. Curr Top Nutraceut $R$ 3: 29-46.

Ghasemzadeh A, Jaafar HZE, Juraimi AS, TayebiMeigooni A. 2015. Comparative evaluation of different extraction techniques and solvents for the assay of phytochemicals and antioxidant activity of hashemi rice bran. Molecules 20: 10822-10838. DOI: $10.3390 /$ molecules 2006108 22.

Gholamhoseinian A, Shahouzehi B, Sharifi-Far F. 2010. Inhibitory activity of some plant methanol extracts on 3-hydroxy-3-methylglutaryl coenzyme a reductase. Int J Pharmacol 6: 705-711. DOI: 10.3923/ijp.2010.705.711.

Goufo P, Trindade H. 2014. Rice antioxidants: phenolic acids, flavonoids, anthocyanins, proanthocyanidins, tocopherols, tocotrienols, $y$-oryzanol, and phytic acid. Food Sci Nutr 2: 75-104. DOI: 10.1002/fsn3.86. 
Hasanah Q, Hasim, Faridah DN, Andrianto D. 2016. Inhibition activity of HMG-CoA reductase by rice brain extract and its fraction as anticholesterolemia In vitro study. Der Pharma Chemica 8: 1-5.

Hasim, Andrianto D, Satyaningtijas AS, Rosary F. 2015. Combination of angkak (Red yeast rice), red guava (Psidium guajava Linn) leaf extract and red guava fruit juice increase thrombocyte in quinine-exposed rats. IOSR J Pharm 5: 1-6.

Iqbal D, Khan MS, Khan A, Khan MS, Ahmad S, Srivastava AK, Bagga P. 2014. In vitro screening for $\beta$-hydroxy- $\beta$-methulglutaryl-CoA reductase inhibitory and antioxidant activity of sequentially extracted fractions of ficus palmata forsk. Biomed Res Int 2014: 1-10. DOI: 10.115 5/2014/762620.

Ismail Al, Hasim, Falah S, Faridah DN. 2016. aGlucosidase inhibition by red yeast rice extract and fractions as in vitro antidiabetes. Der Pharma Chemica 8: 46-49.

Kasim E, Kurniawati Y, Nurhidayat N. 2006. Pemanfaatan isolat lokal Monascus purpureus untuk menurunkan kolesterol darah pada tikus putih galur sprague dawley. Biodiversitas 7: 123-126. DOI: 10.13057/biodiv/d070206.

Kasim E, Triana E, Yulinery T, Nurhidayat N. 2012. Pengaruh angkak hasil fermentasi oleh monascus purpureus $\mathrm{JMBa}$ terhadap aktivitas antioksidan dan gluthation perosidase (GPx) serta histopatologi hati tikus galur sprague dawley. Berita Biologi 11: 177-185.

Kawuri R. 2013. Red mold rice (angkak) sebagai makanan terfermentasi dari China: Suatu kajian pustaka. J Biologi Udayana 17: 24-28.

Kim SM, Lim ST. 2016. Enhanced antioxidant activity of rice bran extract by carbohydrase treatment. J Cereal Sci 68: 116-121. DOI: 10.101 6/j.jcs.2016.01.006.

Koo M, Kim SH, Lee N, Yoo MY, Ryu SY, Kwon DY, Kim YS. 2008. 3-Hydroxy-3-methylglutaryl-CoA (HMG-CoA) reductase inhibitory effect of Vitis vinifera. Fitoterapia 79: 204-206. DOI: 10.101 6/j.fitote.2007.11.005.

Lachenmeier DW, Monakhova YB, Kuballa T, Löbell-Behrends S, Maixner S, Kohl-Himmelseher M, Waldner A, Steffen C. 2012. NMR evaluation of total statin content and HMG-CoA reductase inhibition in red yeast rice (Monascus spp.) food supplements. Chin Med-Uk 7: 8. DOI: 10.1186/1749-8546-7-8.

Liu J, Zhang J, Shi Y, Grimsgaard S, Alraek T, Fonnebo V. 2006. Chinese red yeast rice (Monascus purpureus) for primary hyperlipidemia: a meta-analysis of randomized controlled trial.
Chin Med-Uk 1: 1-13. DOI: 10.1186/ 17498546-1-4.

Maiolino G, Rossitto G, Caielli P, Bisogni V, Rossi GP, and Calò LA. 2013. The role of oxidized low-density lipoproteins inatherosclerosis: The myths and the facts. review article. Mediat Inflamm 2013: 1-13 DOI: 10.1155/2013/714653.

Mei LX, Hai SX, Wen DZ, Ren SG. 2011. Advances on the pharmacological effects of red yeast rice. Chin J Nat Medicines 9: 161-166.

Moongngarm A, Daomukda N, Khumpika S. 2012. Chemical compositions, phytochemicals, and antioxidant capacity of rice bran, rice bran layer, and rice germ. APCBEE Proc 2: 73-79. DOI: 10.1016/j.apcbee.2012.06.014.

Okwuosa IS, Lewsey SC, Adesiyun T, Blumenthal RS, Yancy CW. 2016. Worldwide disparities in cardiovascular disease: Challenges. Int $\mathrm{J}$ Cardiol 202: 433-440. DOI: 10.1016/j.ijcard.2015. 08.172 .

Park HJ, Kim IS. 2011. Antioxidant activities and anticancer effects of red yeast rice grown in the medium containing garlic. Food Sci Biotechnol 20: 297-302. DOI: 10.1007/s10068-011-0042-5.

Peng LX, Zou L, Wang JB, Zhao JL, Xang DB, Zhao G. 2015. Flavonoids, antioxidant activity and aroma compounds analysis from different kinds of tartary buckwheat tea. Indian J Pharm Sci 77: 661-667. DOI: 10.4103/0250-474X.174972.

Pichandi S, Pasupathi P, Raoc YY, Farook J, Ambika A, Ponnusha BS, Subramaniyam S, Virumandy R, Subramaniyam B. 2011. The role of statin drugs in combating cardiovascular diseases. Int J Curr Sci Res 1: 47-56.

Razak DLA, Rashid NYA, Jamaluddin A, Sharifudin SA, Long K. 2014. Enhancement of phenolic acid content and antioxidant activity of rice bran fermented with rhizopus oligosporus and monascus purpureus. Biocatal Agr Biotechnol 4: 33-38. DOI: 10.1016/j.bcab.2014.11.003.

Salvamani S, Gunasekaran B, Shukor MY, Shaharuddin NA, Sabullah MK, Ahmad SA. 2016. Anti-HMG-CoA reductase, antioxidant, and anti-inflammatory activities of Amaranthus viridis leaf extract as a potential treatment for hypercholesterolemia. Evid-Based Compl Alt 2016: 1-10. DOI: 10.1155/2016/8090841.

Singh UN, Kumar S, Dhakal S. 2017. Study of oxidative stress in hypercholesterolemia. Int $\mathrm{J}$ Contemp Med Res 4: 1204-1207.

Tananuwong K, Tewaruth W. 2010. Extraction and application of antioxidants from black glutinous rice. LWT-Food Sci Technol 43: 476-481. DOI: 10.1016/j.Iwt.2009.09.014. 
Tursiman, Ardiningsih P, Nofiani R. 2012. Total fenol fraksi etil asetat dari buah asam kandis (Garcinia dioica Blime). J Kimia Khatulistiwa 1: 4548.

Valko M, Leibfritz D, Moncol J, Cronin MTD, Mazur M, Telser J, 2007. Free radicals and antioxidants in normal physiological functions and human disease. Int J Biochem Cell Biol 39: 44-84. DOI: 10.1016/j.biocel.2006.07.001.

Vongsak B, Sithisarna P, Mangmool S, Thongpraditchote S, Wongkrajang Y, Gritsanapan W. 2012. Maximizing total phenollics, total flavornoids contents and antioxidant activity of moringa oleifera leaf extract by the appropriate ex- traction method. Ind Crop Prod 44: 566-571. DOI: 10.1016/j.indcrop.2012.09.021

Wahyuningrum I, Zubaidah E. 2016. Pengaruh angkak dengan penambahan bekatul terhadap penurunan profil lipid tikus wistar jantan hiperkolesterolemia. J Pangan Agroind 4: 127-136.

[WHO] World Health Organization. 2015. Data Statistik Kesehatan.

Yeap SK, Beh BK, Kong J, Ho WY, Yusof HY, Mohamad NE, Hussin A, Jaganath IB, Alitheen NB, Jamaluddin A. 2014. In vivo hypocholesterolemic effect of MARDI fermented red yeast rice water extract in high cholesterol diet fed mice. Evid-Based Compl Alt 2014: 1-7. DOI: 10. $1155 / 2014 / 707829$ 